\title{
Epidemiology of drug resistance: The case of Staphylococcus aureus and coagulasenegative staphylococci infections
}

\author{
Ernesto Calderón-Jaimes, MC, MSP,(1) Luz E Espinosa de los Monteros, Dra en $C_{1}^{(1)}$ \\ Renata Avila-Beltrán, MC. ${ }^{(1)}$
}

\section{Calderón-Jaimes E, Espinosa de los Monteros LE, Avila-Beltrán R. Epidemiology of drug resistance: The case of Staphylococcus aureus and coagulase-negative staphylococci infections. Salud Publica Mex 2002;44:108-112. \\ The English version of this paper is available too at: http:// www.insp.mx/salud/index.html}

\begin{abstract}
A bstract
objective. To study the activity of several antibiotics against Staphylococcus spp. Material and Methods. The study included 1209 strains of Staphylococcus spp. from two institutions; Instituto $\mathrm{N}$ acional de Pediatría (N ational Institute of Pediatrics) and Hospital Infantil de México Federico Gómez (Mexico City Children's Hospital). Minimum Inhibitory Concentrations of all antibiotics were determined by the agar macrodilution technique and standard methods from the $\mathrm{N}$ ational Committee for Clinical Laboratory Standards. Results. Resistance of $S$. aureus was $14.2 \%$ and that of coagulase-negative staphylococci was $53.4 \%$. The activity of different antibiotics is presented in detail. conclusions. Surveillance of strains resistant to methicillin is necessary. The English version of this paper is available too at: http://www.insp.mx/salud/index.html
\end{abstract}

Key words: drug resistance, microbial; Staphylococcus aureus; coagulase-negative Staphylococcus; antimicrobial susceptibility; methicillin-resistant staphylococci; Mexico

\author{
Calderón-Jaimes E, Espinosa de los Monteros LE, \\ Avila-Beltrán R. \\ Epidemiología de la resistencia bacteriana: \\ el caso de Staphylococcus aureus \\ y las infecciones Staphylococcuscoagulasa negativas. \\ Salud Publica Mex 2002;44:108-112. \\ EI texto completo en inglés de este artículo también \\ está disponible en: http://www.insp.mx/salud/index.html
}

\section{Resumen}

abjetivo. Determinar la frecuencia de la resistencia a la meticilina y la actividad de varios antibióticos. Material y métodos. Se incluyeron 1209 cepas de Staphylococcus spp. procedentes de pacientes del Instituto $\mathrm{N}$ acional de Pediatría y del Hospital Infantil de México Federico Gómez. Se utilizó la técnica de dilución en placas con agar. El procedimiento e interpretación fueron acordes con lo establecido por el $\mathrm{N}$ ational Committee for Clinical Laboratory Standards. Resultados. La frecuencia de la resistencia de $S$. aureus fue de $14.2 \%$ y de $53.4 \%$ en los Staphylococcus coagulasa negativa. La actividad de otros antimicrobianos se presenta en el texto. Conclusiones. Es necesario vigilar continuamente la progresión de la resistencia de Staphylococcus Spp. a la meticilina.El texto completo en inglés de este artículo también está disponible en: http://www.insp.mx/salud/index.html

Palabras clave: resistencia microbiana a las drogas; Staphylococcus aureus; Staphylococcus coagulasa negativa; sensibilidad antimicrobiana; estatilococos metilicina resistentes; México

(1) Departamentos de Bacteriología Intestinal, Inmunoquímica y Biología Celular. Hospital Infantil de México "Federico Gómez". México, D.F., México.

Received on: A pril 3, 2001 - Accepted on: 0 ctober 19, 2001

Address reprint requests to: Dr. E. Calderón. Subdirección de Investigación, Departamento de Inmunoquímica y Biología Celular, Hospital Infantil de México "Federico Gómez". Dr. Márquez N o. 162, colonia Doctores, 06720 México, D.F., México.

E-mail: ecalderj@yahoo.com 
$S_{s}$ aphylococcus aureus remains a versatile and dan gerous pathogen in humans, since it is one of the most common causes of nosocomial and communityacquired infection. SA infections are often acute and pyogenic, and if untreated, may spread to surrounding tissue or via bacteremia to metastatic sites. ${ }^{1-3}$

Some of the most common infections caused by SA involve the skin, including furuncles, cellulitis, impetigo, and postoperative wound infections of various sites. Some of the most serious infections produced by SA are bacteremia, pneumonia, osteomyelitis, endocarditis, scalded skin syndrome, empyema, toxic shock syndrome, and abscesses of the muscle and various intra-abdominal organs. ${ }^{4-8}$

The role of coagulase-negative staphylococci in causing nosocomial infections has been recognized and well documented over the last two decades, specially for the species $S$. epidermidis. The infection rate has been correlated with the increase in the use of prosthetic and indwelling devices and the growing number of immunocompromised patients in hospitals. Nosocomial infections have been a mayor cause of morbidity and mortality. ${ }^{9-12}$

Methicillin-resistant staphylococci have become a serious problem in many parts of the world. Although the incidence of methicillin-resistant strains of staphylococci varies from country to country and from hospital to hospital, it has been steadily increasing worldwide in the last decade. ${ }^{13-16}$

The present work was carried out to study the activity of several antimicrobials against $S$. aureus and coagulase negative staphylococci strains recovered from patients with severe infections.

\section{Material and Methods}

This study included 296 Staphylococcus strains (84 S. aureus and 212 coagulase-negative staphylococci strains) collected in patients from the National Institute of Pediatrics during 1998-1999, and 913 Staphylococcus strains (127 S. aureus and 786 coagulase-negative staphylococci strains) collected in patients from Hospital Infantil de México Federico Gómez during 1998-2000; both of these hospitals are tertiary care referral centers. Data for each strain was obtained from the Institutional Surveillance System for Antimicrobial Resistance, to monitor the frequency of occurrence and antimicrobial susceptibility of both nosocomial and communityacquired bacterial pathogens.

The organisms were recovered from a variety of clinical specimens, including normally sterile body fluids (71 in blood; 165 in CSF, mainly from ventriculitis; 53 in pleural fluid; 22 in peritonitis; 7 in joint fluid; 265 in abscesses; 65 in urine cultures; 36 in dialysis, and 525 in prosthetic and indwelling devices, mainly catheters). Only one isolate from each clinical episode was included in the analyses. Isolates (coagulase-negative staphylococci) were judged to be clinically significant by two criteria: a) isolation of strain in pure culture from the infected site or body fluid, $b$ ) repeated isolation of the same strain over the course of the infection. Staphylococcus strains were kept frozen at $-70{ }^{\circ} \mathrm{C}$ until testing. ${ }^{17}$

Antimicrobials used in this study were oxacillin, amoxicillin-clavulanate, ticarcillin-clavulanate, cefepime, ceftriaxone, imipenem, clarithromycin, gentamicin, amikacin, ciprofloxacin, teicoplanin, vancomicyn, and linezolid. The agents were supplied as laboratory powders of known potency, and stock solutions were made as recommended by the manufacturers.

Prior to being tested, each isolate was subcultured at least twice on mannitol and $\mathrm{NaCl}$ agar plates (BBL, Mexico) to ensure purity and optimal characteristics. Minimum Inhibitory Concentrations (MIC) of all of antibiotics tested were determined by use of a broth macrodilution technique and standard methods defined by the National Committee for Clinical Laboratory Standards (NCCLS). ${ }^{18,19}$ Mueller-Hinton broth was used as the growth medium throughout the study (BBL, Mexico). The final bacterial inoculum concentration used was $5 \times 10^{5} \mathrm{cfu} / \mathrm{mL}$. Trays were incubated 24 $h$ at $35{ }^{\circ} \mathrm{C}$ in ambient air before determination of MIC values. National Committee for Clinical Laboratory Standards breakpoints were used to interpret MIC data. Appropriate quality control was performed by use of Staphylococcus aureus ATCC 29213 (oxacillin susceptible). Linezolid is an investigational drug; no susceptibility breakpoints are available for it. The manufacturer defined $\leq 4 \mu \mathrm{g} / \mathrm{mL}$ as susceptible and $\geq$ $4 \mu \mathrm{g} / \mathrm{mL}$ as resistant.

The current NCCLS breakpoint for oxacillin susceptibility for Staphylococcus was MIC $\leq 2 \mu \mathrm{g} / \mathrm{mL}$ for susceptible strains and MIC $\geq 4 \mu \mathrm{g} / \mathrm{mL}$ for resistant strains. All isolates were screened for methicillin resistance on Mueller-Hinton agar added with $\mathrm{NaCl}$ $(2 \%)$. Colonies that grew only on oxacillin-free plates and were both mannitol and coagulase-positive, were considered methicillin susceptible Staphylococcus aureus (MSSA) Coagulase-positive organisms that also grew on mannitol salt plates with oxacillin were identified as methicillin resistant Staphylococcus aureus. Coagulase-negative staphylococci were also probed and considered in accordance as coagulase-negative methicillin susceptible or coagulase-negative methicillin resistant. 


\section{Results}

Susceptibility to oxacillin differed significantly among staphylococci, with $14.2 \%$ of $S$. aureus isolates and $53.4 \%$ of coagulase-negative staphylococci isolates showing resistance to oxacillin, and therefore were cross-resistant to all other $\beta$-lactam compounds. Oxacillin-dicloxacillin, and also other useful antistaphylococcal compounds, were predictably highly active against oxacillin-susceptible isolates.

Regarding non- $\beta$-lactam antibiotics, all staphylococci remained fully susceptible to the glycopeptide antibiotics vancomycin and teicoplanin $\left(\mathrm{MIC}_{90} \leq 2\right.$ $\mu \mathrm{g} / \mathrm{mL}$ ). Linezolid, a new class of antimicrobial agent that inhibits bacterial protein synthesis by blocking formation of the initiation complex, demonstrated 100\% activity against all Staphylococcus in this in vitro study.

Few oxacillin-resistant staphylococci were susceptible to ciprofloxacin, whereas $81 \%$ of the oxacillinsusceptible $S$. aureus were susceptible to amikacin. A total of $94.4 \%$ of the coagulase-negative oxacillin-susceptible strains were also susceptible to that aminoglycoside. Reduced susceptibility to all other drugs tested was higher among methicillin-resistant than among methicillin-susceptible isolates, especially susceptibility to clarithromycin and gentamicin.

The activity of different antibiotics against $S$. aureus and coagulase-negative staphylococci is shown in tables I and II.

\section{Discussion}

The development of antimicrobial resistance nearly always has followed the therapeutic use of antimicrobial agents. When penicillin was introduced for clinical use, virtually all strains of $S$. aureus were susceptible. Unfortunately, within less than a decade, serious resistance problems were seen in many major medical centers. $S$. aureus acquired $\beta$-lactamase genes, rendering the organism penicillin-resistant. To combat this problem, researchers developed extended-spectrum penicillins and cephalosporins. These new antimicrobials succeeded only partially in overcoming the problem of resistance. Methicillin-resistant strains of staphylococci have been known since the early 1960s. Recently, strains relatively resistant to glycopeptides have been described (MIC $\leq 8$ $\mu \mathrm{g} / \mathrm{mL}){ }^{15}$ Treatment of Staphylococcus infections has become more difficult because of multidrug-resistant strains.

Staphylococcus aureus and coagulase-negative staphylococci have been identified by the National Nosocomial Infections Surveillance system as the leading overall causes of hospital acquired infections. 5,15,20

The percentage of methicillin-resistant $S$. aureus (MRSA) in hospitals in the United States rose from $2.4 \%$ in 1975 to $29 \%$ in 1991, with a methicillinresistant Staphylococcus aureus rate of 38\% at large hospitals. ${ }^{3}$ The highest resistance rates occurred among isolates from patients in intensive care units,

Table I

ACtIVITY ( $\mu \mathrm{G} / \mathrm{ML}$ ) SPECTRUM OF VARIOUS ANTIMICROBIAL AGENTS AGAINST 211 STRAINS of Staphylococcus aureus. Mexico, D.F., MeXico, 1998-1999

\begin{tabular}{|c|c|c|c|c|c|c|}
\hline \multirow[b]{2}{*}{ Drugs } & \multicolumn{2}{|c|}{$\begin{array}{c}\text { Methicillin-susceptible } \\
\text { Staphylococcus aureus }(n=\mid 8 I)\end{array}$} & \multirow{2}{*}{$\begin{array}{c}\text { Susceptible } \\
\%\end{array}$} & \multicolumn{2}{|c|}{$\begin{array}{c}\text { Methicillin-resistant } \\
\text { Staphvlococcus aureus }(n=30)\end{array}$} & \multirow{2}{*}{$\begin{array}{c}\text { Susceptible } \\
\%\end{array}$} \\
\hline & $\begin{array}{l}\text { Minimum inhibitory } \\
\text { concentration }_{50}\end{array}$ & $\begin{array}{l}\text { Minimum inhibitory } \\
\text { concentration }_{90}\end{array}$ & & $\begin{array}{l}\text { Minimum inhibitory } \\
\text { concentration }_{50}\end{array}$ & $\begin{array}{l}\text { Minimum inhibitory } \\
\text { concentration }_{90}\end{array}$ & \\
\hline 0 xacillin & $<0.5$ & $<2$ & 94.4 & $>16$ & $>16$ & 0 \\
\hline Amoxacillin-clavulanate & 1 & 2 & 94.0 & $>16$ & $>16$ & 0 \\
\hline Ticarcillin-clavulanate & 1 & 4 & 92.8 & $>16$ & $>16$ & 0 \\
\hline Cefepime & 2 & 4 & 97.2 & $>16$ & $>16$ & 0 \\
\hline Ceftriaxone & 2 & 4 & 95.0 & $>16$ & $>16$ & 0 \\
\hline Imipenem & 0.12 & 0.25 & 97.2 & $>8$ & $>8$ & 0 \\
\hline Clarithromycin & 0.5 & $>8$ & 76.2 & $>8$ & $>8$ & 10 \\
\hline Gentamicin & 0.5 & 2 & 92.8 & $>16$ & $>16$ & 16.6 \\
\hline Amikacin & 0.5 & 1 & 94.4 & $>8$ & $>8$ & 16.6 \\
\hline Ciprofloxacin & 0.25 & 2 & 88.3 & $>2$ & $>2$ & 10 \\
\hline Teicoplanin & 0.5 & 1 & 100.0 & 1 & 2 & 96.6 \\
\hline Vancomycin & 1 & 1 & 100.0 & 1 & 2 & 100 \\
\hline Linezolid* & $<0.25$ & 2 & 100.0 & 1 & 2 & 100 \\
\hline
\end{tabular}


Table II

\section{ACtivity ( $\mu \mathrm{G} / \mathrm{ML})$ SPECTRUM OF VARIOUS ANTIMICROBIAL AGENTS AGAINST 998 StRains of Coagulase-negative staphylococci. Mexico, D.F., Mexico, 1998-1999}

\begin{tabular}{|c|c|c|c|c|c|c|}
\hline \multirow[b]{2}{*}{ Drugs } & \multicolumn{2}{|c|}{$\begin{array}{c}\text { Methicillin susceptible } \\
\text { coagulase-negative staphylococci }(n=465)\end{array}$} & \multirow{2}{*}{$\begin{array}{c}\text { Susceptible } \\
\%\end{array}$} & \multicolumn{2}{|c|}{$\begin{array}{l}\text { Methicillin-resistant } \\
\end{array}$} & \multirow{2}{*}{$\begin{array}{c}\text { Susceptible } \\
\%\end{array}$} \\
\hline & $\begin{array}{l}\text { Minimum inhibitory }^{\text {concentration }_{50}}\end{array}$ & $\begin{array}{l}\text { Minimum inhibitory } \\
\text { concentration }_{90}\end{array}$ & & $\begin{array}{l}\text { Minimum inhibitory } \\
\text { concentration }_{50}\end{array}$ & $\begin{array}{l}\text { Minimum inhibitor } \\
\text { concentration }_{90}\end{array}$ & \\
\hline 0 xacillin & $<1$ & $<2$ & 98.9 & 4 & $>16$ & 0 \\
\hline Amoxicillin-clavulanate & 0.5 & 2 & 97 & 8 & $>16$ & 0 \\
\hline Ticarcillin-clavulanate & 0.25 & 2 & 97 & 4 & $>16$ & 0 \\
\hline C efepime & 1 & 4 & 98.9 & 8 & $>16$ & 0 \\
\hline Ceftriaxone & 1 & 8 & 91.8 & 16 & $>16$ & 0 \\
\hline Imipenem & 0.12 & 0.25 & 98.9 & 1 & $>8$ & 0 \\
\hline Clarithromycin & 0.5 & $>8$ & 40.7 & $>8$ & $>16$ & 18.2 \\
\hline Gentamicin & 0.12 & 16 & 81 & 8 & $>16$ & 28.3 \\
\hline Amikacin & 0.12 & 16 & 81 & 8 & $>8$ & 28.3 \\
\hline Ciprofloxacin & 0.12 & $>2$ & 43 & 4 & $>4$ & 43 \\
\hline Teicoplanin & 1 & 2 & 100 & 1 & 4 & 100 \\
\hline Vancomycin & 0.5 & 2 & 100 & 1 & 2 & 100 \\
\hline Linezolid* & 0.25 & 2 & 100 & 0.5 & 2 & 100 \\
\hline
\end{tabular}

followed in decreasing order by rates among isolates from outpatients. These organisms included methicillin-resistant coagulase-negative staphylococci in intensive care units $(75 \%)$, non-ICUs $(60.4 \%)$ and outpatient areas (44.5\%); and MRSA in intensive care units $(35.2 \%)$, non-intensive care units $(31.9 \%)$ and outpatients areas $(17.7 \%){ }^{21}$

S. aureus and coagulase-negative staphylococci are virulent pathogens that are currently the most common cause of infections in hospitalized patients. Increasing resistance to antibiotics indicates that their prevalence will continue to rise.

Given the number and severity of staphylococcal infections, it is important to understand the nature and pathogenesis of infections and the current strategies available for therapy and prevention.

The core resistance phenotype that seems to be mostly associated with the persistence of $S$. aureus in the hospital is methicillin resistance. This resistance is due to the acquisition of a new penicillin-binding protein, PBP2a. ${ }^{14}$ This protein has low affinity for most $\beta$-lactam antibiotics, and therefore, mediates cross-resistance to all these compounds. . $^{3,14}$

Methicillin resistance in nosocomial isolates of $S$. aureus and coagulase-negative staphylococci has been dramatically increasing, and is also associated with resistance to other useful antistaphylococcal compounds. ${ }^{15,20}$
This high level of resistance not only impedes successful therapy for infections but also allows the organism to persist in the hospital, expanding its reservoir. Study results suggest that the current levels of methicillin-resistance in $S$. aureus and CNS have a similar pattern to what has already been established. ${ }^{15}$

Although the incidence of- methicillin resistant S. aureus and methicillin-resistant Staphylococcus epidermidis strains and other methicillin resistant staphylococci varies from hospital to hospital, it has been increasing and often exceeds $50 \%$, as is in the case of coagulase-negative methicillin resistant staphylococ$\mathrm{ci}$, which is a major cause of medical device-associated infections, specially in immunocompromised patients, and the excessive use of vancomycin in the empirical treatment is complicated by the emergence of multiresistant strains. ${ }^{15}$

A semisynthetic penicillin (dicloxacillin) would be the drug of choice for b-lactamase-producing strains, as well as in the case of $S$. aureus and methicillin-susceptible coagulase-negative staphylococci. Cephalotin and clindamycin are acceptable alternatives. Vancomycin should be reserved to treat methicillin-resistant proved cases. The extensive use of vancomycin may help promote colonization and infections with vancomycin enterococci.

Today, chemotherapy for Staphylococcus methicillin-resistant infections is becoming increasingly dif- 
ficult. With the increasing frequency of nosocomial and device-related infections associated with methicillin-resistant staphyloccocus epidermidis, and the failure of glycopeptide antibiotic therapy in those infections, the pharmaceutical industry is searching and responding with alternative agents, such as a combination drug consisting of semisynthetic derivatives of streptogramin A (dalfopristin) and streptogramin B (quinupristin) (Synercid), used in Europe for several years with no significant increase in resistance over time. ${ }^{22}$

The oxazolidinone antibiotics (PNU-1000766 and PNU-100592, Linezolid and Eperezolid), are other novel antimicrobial agents that have been shown to be active against most medically important gram-positive bacteria. In our study, the in vitro activity of Linezolid against Staphylococcus, either methicillin susceptible or resistant, was comparable with those of vancomycin. ${ }^{23}$

Since antibiotic use became widespread 50 years ago, bacteria have steadily and routinely developed resistance. Control of the emergence of resistance will depend on new approaches to prudent antibiotic use in hospitals and clinics, based in part on improved surveillance for methicillin-resistance staphylococci by currently available methods and on better systems to encourage staff adherence to follow isolation procedures.*

\section{Acknowledgements}

We acknowledge the partial support of Pharmacia and Upjohn (Dra. Susana Suárez). The authors are grateful to QBP, MSc, Norma Velázquez for technical assistance.

\section{References}

1. Lowy FD. Staphylococcus aureus infection. N Engl J Med 1998;320: 520-532.

2. Crossley KB, Archer GL, ed. The staphylococci in human diseases. N ueva York: Churchill Livingstone, 1997.

3. Archer GL. Staphylococcus aureus: A well-armed pathogen. Clin Infect $\mathrm{D}$ is 1998;26:1179-1181.

4. Conterno LO, W ey SB, Castelo A. Risk factors for mortality in Staphylococcus aureus bacteremia. Infect Control Hosp Epidemiol 1998;19:3237.
5. Romero-Vivas J, Rubio M, Fernández C, Picazo J]. Mortality associated with nosocomial bacteremia due to methicillin-resistant Staphylococcus aureus. Clin Infect D is 1995;21:1417-1423.

6. Musher O M, Lamm N, D aroniche RO, Young EJ, Hamill RJ, Landon GC. The current spectrum of Staphylococcus aureus infection in a tertiary care hospital. Medicine (Baltimore) 1994;73:186-208.

7. Bone RC. Gram-positive organisms and sepsis. Arch Intern Med 1994;154:26-34.

8. W itte W. Antibiotic resistance in gram-positive bacteria: Epidemiologic aspects. J Antimicrob Chemother 1999;44 (Suppl A): 1-9.

9. Kloos W E, Bannerman TL. Update on clinical significance of coagulasenegative staphylococci. Clin Microbial Rev 1994;7:117-140.

10. Viagappan N, Kelsey MC. The origin of coagulase-negative staphylococci isolated from blood cultures. J Hosp Infect 1995;30:217-223.

11. Raad L, Alrahwan A, Rolston K. Staphylococcus epidermidis: Emerging resistance and need for alternative agents. C lin Infect D is 1998; 26:1182-1187.

12. Rupp ME, Archer GL. C oagulase-negative staphylococci: Pathogens associated with medical progress. Clin Infect D is 1994;19:231-243.

13. W aldvogel FA. N ew resistance in Staphylococcus aureus. N Engl J Med 1999;340:556-557.

14. Chambers HF. Methicillin resistance in staphylococci. Molecular and biochemical basis and clinical implications. Clin Microbiol Rev 1997;10: 781-791.

15. Pfaller MA, Jones RN, D oern GV, Sader HS, Kugler KC, Beach ML et al. Survey of bloodstream infections due to gram-positive cocci: Frequency of occurrence and antimicrobial susceptibility of isolates collected in 1997 in the United States, Canada, and Latin America for the SEN TRY antimicrobial surveillance program. Diagn Microbiol Infect D is 1999;33:283-297. 16. Schwalbe RS, Stapleton JT, Gilligan PH. Emergence of vancomycin resistance in coagulase-negative staphylococci. N Engl Med 1987;316: 927-931.

17. Kloos W K, Bannerman TL. Staphylococcus and Micrococcus. En: Murray PR, Baron EJ, Pfaller MA, Tenover FC, Yolken RH, ed. Manual of clinical microbiology. $7^{\text {th }}$ ed. W ashington, D.C.: ASM Press, 1999: 264-282.

18. $\mathrm{N}$ ational Committee for Clinical Laboratory Standards. Antimicrobial susceptibility test for bacteria that grow aerobically: Approved Standard. $5^{\text {th }}$ ed. W ayne (PA): N ational Committee for Clinical Laboratory Standards, 2000; N CCLS document M7-A5.

19. N ational Committee for Clinical Laboratory Standards. Performance standards for antimicrobial susceptibility testing: Tenth informational supplement W ayne (PA): N ational Committee for C linical Laboratory Standards. 2000; M100-S10.

20. Emory TG, Gaynes RP. An overview of nosocomial infections, including the role of the microbiology laboratory. Clin Microbiol Rev 1993;6: 428-442.

21. Fridkin SK, Steward CD, Edwards JR, Pryor EE, MC G owan JE, Archivald LK et al. Surveillance of antimicrobial use and antimicrobial resistance in the United States hospitals: Project IC ARE phase 2. Clin Infect D is 1999; 29: 245-252.

22. Brumfitt W, Hamilton-Miller JM, Shah S. In vitro activity of RP59500 a new semisynthetic antibiotic, against gram-positive bacteria. I Antimicrob Chemother 1992; 30 (Suppl A):27-37.

23. Stevens D L, Smith LG, Bruss JB, McC onnell-Martin MA, D uvall SE, Todd W M et al. Randomized comparison of Linezolid (PNU-100766) versus oxacillin-dicloxacillin for treatment of complicated skin and soft tissue infections. Antimicrob A gents Chemother 2000; 44: 3408-4813. 